\title{
Loop-mediated isothermal amplification (LAMP) assay for the diagnosis of imported malaria: a narrative review
}

\author{
Spinello Antinori ${ }^{1,2}$, Anna Lisa Ridolfo², Romualdo Grande ${ }^{3}$, Laura Galimberti², \\ Giacomo Casalini' ${ }^{1}$, Andrea Giacomelli1,2, Laura Milazzo ${ }^{2}$ \\ 'Department of Biomedical and Clinical Sciences "Luigi Sacco", Università degli Studi di Milano, Milano, Italy; \\ ${ }^{2}$ III Division of Infectious Diseases, ASST Fatebenefratelli Sacco, Luigi Sacco Hospital, Milano, Italy; \\ ${ }^{3}$ Clinical Microbiology, Virology and Bioemergency, ASST Fatebenefratelli Sacco, Luigi Sacco Hospital, Milano, Italy
}

Article received 30 June, 2021; accepted 9 August, 2021

\section{SUMMARY}

Loop-mediated isothermal amplification (LAMP) is a molecular method to detect malaria recently introduced in the market. LAMP is simple to perform and does not require advanced equipment and training thus satisfying the qualification as a point-of-care diagnostic screening test.

In this narrative review, we focus on the role of LAMP for malaria diagnosis in non-endemic settings. We searched PubMed, Embase, Scopus, and Google Scholar, using the following search terms: 'Malaria LAMP' in combination with 'imported malaria' or 'travellers' malaria' or 'non-endemic setting' or 'non-endemic region' or 'malaria screening' or 'malaria diagnosis'. References of each article were also reviewed for possible studies or reports not identified in our search.

Overall, 18 studies encompassing 6289 tested samples with 1663 confirmed malaria diagnoses were retrieved. Most of these studies (13/18, $72.2 \%)$ were conducted in Europe, and almost half were retrospective. Fourteen studies $(77.8 \%)$ employed real-time or nested-polymerase chain reaction as the reference method for confirming malaria diagnosis. Sensitivity of LAMP ranged from 93.9 to $100 \%$ and specificity from 93.8 to $100 \%$ with a negative predictive value of $99.6 \%-100 \%$. The rate of reported invalid results requiring repeat of the test varied from $0.01 \%$ to $5.7 \%$, but they were solved in the majority of cases with a secondary analysis.

In non-endemic countries the adoption of LAMP malaria assay as the screening test for malaria diagnosis seems to perform better than conventional methods. However, blood microscopy remains essential to either identify Plasmodium species and quantify parasitaemia and adequately managing malaria cases.

Keywords: loop-mediated isothermal amplification; malaria; non-endemic setting; rapid diagnostic test; travellers.

\section{INTRODUCTION}

$\mathrm{M}$ alaria remains the most frequent cause of fever among travellers and visiting friends and relatives (VFRs) returning from endemic countries $[1,2]$. Estimates of the World Health Organization $(\mathrm{WHO})$ have shown that the incidence

$\overline{\text { Corresponding author }}$

Spinello Antinori

E-mail: spinello.antinori@unimi.it of malaria has declined globally in recent decades, but the rate of change has slowed markedly in the last five years settling at 57 malaria cases per 1000 population at risk. In 2019 there were a total of 229 millions of malaria cases worldwide with 409000 associated-deaths [3]. Currently, there is a risk of malaria transmission in 87 countries and it has been estimated that 125 million travellers are at risk every year [3]. In Europe 37187 confirmed malaria cases (99.8\% travel-related) were reported between 2014 and 2018 with a steady increase 
starting from 2016 and a peak of 8393 cases in 2017 [4]. In the USA the number of reported malaria cases in the period 2012- 2017 was 10916 with a peak in 2017 (2161 cases) [5].

Plasmodium falciparum malaria may be potentially severe and life-threatening, and therefore should be always considered a medical emergency that requires rapid diagnosis and prompt treatment initiation. Due to nonspecific nature of clinical signs and symptoms, malaria diagnosis needs to be confirmed through parasite-specific laboratory methods. There are different diagnostic malaria methods, including microscopic examination of Giemsa-stained thick and thin blood smears, rapid diagnostic tests (RDTs), and Polymerase Chain Reaction (PCR) or other nucleic-acid based assays [68]. As indicated by the $\mathrm{WHO}$, microscopy remains the mainstay of parasite-based diagnosis of malaria [2]. However, malaria microscopy is a labour intensive method whose quality strongly relies on well experienced personal, and in countries where relatively few cases of malaria are seen it may be difficult to maintain required levels of training also considering of the large number of laboratory staff who alternate in emergency services. Some studies have shown that prompt laboratory malaria diagnosis may be particularly challenging during outof-office hours when competent microscopists may not be available [8-10]. In a study conducted in Portugal half of all malaria smears were performed out-of hours (i.e., other than 9-17 Monday to Friday) but accounted for $61 \%$ of malaria diagnosis [11]. In some hospital laboratories in United Kingdom (UK) as well as in other European countries, after-hours diagnosis of malaria is performed using only immunochromatography-based malaria rapid diagnostic tests (RDTs) [8, 12]. A large survey conducted in Belgium and Luxembourg has also shown that one third of participant laboratories used RDTs alone for malaria diagnosis although this is not a recommended practice [9]. Although RDTs are rapid, easy to use and sensitive for P. falciparum, they lack sensitivity at low parasite density, fail to identify a large number of non-falciparum malaria, do not allow parasite quantification, are prone to some errors in reading and interpreting test lines and result in false negative malaria diagnosis when $P$. falciparum with Histidine Rich Protein 2 (HRP2)-deletion is involved [6, 9, 10, 13]. At present, PCR represents the most sensitive and specific tool for the diagnosis of malaria, but its cost and turnaround time greatly limit its use outside of reference laboratories [11, 14-16]. Thus, blood microscopy and RDT remain the conventional methods used for malaria diagnosis in clinical practice. Recently, new molecular techniques, including the loop-mediated isothermal amplification technology (LAMP), have been added to malaria laboratory diagnostic repertoire. LAMP is based on a onestep molecular amplification technique not requiring cyclical temperature changes and it allows to detect all Plasmodium species (including Plasmodium knowlesi) in less than hour, with sensitivity and specificity close to those of PCR [17-21]. The amplification products of LAMP can be visualised under fluorescence or by densitometry with the caveat that results are qualitative and therefore parasitaemia cannot be estimated [22-24].

It can be therefore a revolutionary tool to be adopted for the diagnosis of malaria in non-endemic countries where good-quality microscopy cannot always be guaranteed.

We carried out a review of the literature with the aim to verify the sensitivity and specificity of LAMP for the diagnosis of imported malaria.

\section{MATERIALS AND METHODS}

A comprehensive search of the PubMed MEDLINE, Embase, Scopus and Google Scholar online databases was performed with the search terms 'LAMP' AND 'imported malaria' OR 'travellers' malaria' OR 'non-endemic setting' OR 'non-endemic region' OR 'malaria screening' OR 'malaria diagnosis'. The search was limited to include only peer reviewed journal articles that were written in English, were published between 2000 (when LAMP was first described) and 2019 (including ahead of print articles) and focused on subjects residing in countries non-endemic for malaria. Single case reports, reviews and studies conducted in non-endemic setting using samples from patients living in endemic countries were excluded. We also reviewed the references of each article to further include other studies or reports not identified by the search.

\section{RESULTS}

Characteristics of retrieved studies

We retrieved 18 studies regarding the use of LAMP assay for the diagnosis of malaria in samples ob- 
tained from subjects living in non-endemic countries exposed to malaria risk (Table 1) [17-34].

Of these studies, 8 analysed archived blood samples or dried blood spots [19, 22, 23, 25-27, 32, 33], 9 studies analysed prospectively collected blood samples $[17,18,20,21,24,29,30,31,34]$ and one included both archived and prospectively collected blood samples [28]. Thirteen studies were carried out in Europe (3 in UK, 2 each in France, Germany and Belgium, 1 in multiple European

Table 1 - Studies regarding the use of Loop-mediated isothermal amplification (LAMP) for the diagnosis of malaria in non-endemic countries.

\begin{tabular}{|c|c|c|c|c|c|c|c|c|c|c|}
\hline \multirow{2}{*}{$\begin{array}{l}\text { Author, } \\
\text { year of } \\
\text { publication } \\
\text { [reference] }\end{array}$} & \multirow[b]{2}{*}{ Country } & \multirow[b]{2}{*}{$\begin{array}{c}\text { Type/Period } \\
\text { of study }\end{array}$} & \multirow{2}{*}{$\begin{array}{c}\text { Reference } \\
\text { standard } \\
\text { method }\end{array}$} & \multirow[b]{2}{*}{$\begin{array}{c}\text { LAMP } \\
\text { assay type }\end{array}$} & \multirow{2}{*}{$\begin{array}{l}\quad N^{\circ} \text { of } \\
\text { samples (s) } \\
\text { or patients } \\
\text { (p) tested }\end{array}$} & \multirow{2}{*}{$\begin{array}{l}N^{\circ}(\%) \\
\text { malaria } \\
\text { positive }\end{array}$} & \multicolumn{4}{|c|}{ Performance of LAMP assay } \\
\hline & & & & & & & $\begin{array}{c}\text { Sensitivity } \\
\%\end{array}$ & $\begin{array}{c}\text { Specificity } \\
\%\end{array}$ & $\begin{array}{c}P P V \\
\%\end{array}$ & $\begin{array}{c}N P V \\
\%\end{array}$ \\
\hline $\begin{array}{l}\text { Polley, } \\
2010 \text { [19] }\end{array}$ & UK & $\begin{array}{c}\text { Retrospective } \\
\text { (archived } \\
\text { WBS)/ } \\
\text { Oct. -Nov. } \\
2008\end{array}$ & $\begin{array}{l}\text { Nested } \\
\text { PCR }\end{array}$ & $\begin{array}{l}\text { In-house } \\
\text { with pan- } \\
\text { genus (Pan) } \\
\text { and } P \text {. } \\
\text { falciparum } \\
\text { (Pf) specific } \\
\text { primers }\end{array}$ & $143(\mathrm{~s})$ & $33(23.1)$ & $\begin{array}{l}93.9^{*} \\
93.3^{\S}\end{array}$ & $\begin{array}{l}100^{*} \\
100^{\S}\end{array}$ & $\begin{array}{l}\text { NR } \\
\text { NR }\end{array}$ & $\begin{array}{l}\text { NR } \\
\text { NR }\end{array}$ \\
\hline $\begin{array}{l}\text { Polley, } \\
2013 \text { [20] }\end{array}$ & UK & $\begin{array}{l}\text { Prospective/ } \\
\text { Jan.-Jul. } \\
2011\end{array}$ & $\begin{array}{l}\text { Nested } \\
\text { PCR }\end{array}$ & $\begin{array}{l}\text { Loopamp } \\
\text { Malaria } \\
\text { Pan/Pf kit, } \\
\text { Eiken }\end{array}$ & $705(\mathrm{~s})$ & $67(9.5)$ & $\begin{array}{c}97^{\star} \\
98.4^{\S}\end{array}$ & $\begin{array}{l}99.2^{*} \\
98.1^{\S}\end{array}$ & $\begin{array}{l}92.7^{*} \\
83.5^{\S}\end{array}$ & $\begin{array}{l}99.7^{*} \\
99.8^{\S}\end{array}$ \\
\hline $\begin{array}{l}\text { Marti, } \\
2015 \text { [21] }\end{array}$ & Switzerland & $\begin{array}{l}\text { Prospective } \\
\text { / Mar.-Oct. } \\
2012\end{array}$ & RT- PCR & $\begin{array}{l}\text { Loopamp } \\
\text { Malaria } \\
\text { Pan/Pf kit }\end{array}$ & $205(\mathrm{~s})$ & $47(22.9)$ & $100^{*}$ & $100^{*}$ & $91.5^{*}$ & $100^{*}$ \\
\hline $\begin{array}{l}\text { Lucchi, } \\
2016 \text { [22] }\end{array}$ & USA & $\begin{array}{c}\text { Retrospective } \\
\text { (archived } \\
\text { WBS)/ NR }\end{array}$ & $\begin{array}{l}\text { RT (PET)- } \\
\text { PCR }\end{array}$ & $\begin{array}{l}\text { In-house } \\
\text { malachite } \\
\text { green (pan) } \\
\text { LAMP }\end{array}$ & $190(\mathrm{~s})$ & $151(79.5)$ & 100 & 100 & NR & NR \\
\hline $\begin{array}{l}\text { Mohon, } \\
2016 \text { [23] }\end{array}$ & Canada & $\begin{array}{l}\text { Retrospective } \\
\text { (archived } \\
\text { WBS)/ } \\
\text { 2003-2014 }\end{array}$ & $\begin{array}{l}\text { Nested } \\
\text { PCR }\end{array}$ & $\begin{array}{l}\text { Loopamp } \\
\text { Malaria } \\
\text { Pan/Pf kit }\end{array}$ & $140(\mathrm{~s})$ & $71(50.7)$ & $\begin{array}{l}100^{*} \\
97.6^{\S}\end{array}$ & $\begin{array}{l}98.6^{*} \\
100^{\S}\end{array}$ & $\begin{array}{l}\text { NR } \\
\text { NR }\end{array}$ & $\begin{array}{l}\text { NR } \\
\text { NR }\end{array}$ \\
\hline $\begin{array}{l}\text { Van Gool, } \\
2017 \text { [24] }\end{array}$ & $\begin{array}{l}\text { Belgium, } \\
\text { Netherlands }\end{array}$ & $\begin{array}{l}\text { Prospective } \\
\text { / Apr. 2016- } \\
\text { Mar. } 2017\end{array}$ & RT-PCR & $\begin{array}{l}\text { Illumigene } \\
\text { Malaria kit } \\
\text { Illumigene } \\
\text { Malaria Plus } \\
\text { kit }\end{array}$ & $273(\mathrm{p})$ & $147(53.8)$ & $\begin{array}{l}100 \\
100\end{array}$ & $\begin{array}{l}100 \\
100\end{array}$ & $\begin{array}{l}\text { NR } \\
\text { NR }\end{array}$ & $\begin{array}{l}\text { NR } \\
\text { NR }\end{array}$ \\
\hline $\begin{array}{l}\text { Cuadros, } \\
2017 \text { [25] }\end{array}$ & $\begin{array}{l}\text { Multiple } \\
\text { European } \\
\text { centers }\end{array}$ & $\begin{array}{c}\text { Retrospective } \\
\text { (archived } \\
\text { WBS)/Jun. } \\
\text { 2014-Mar. } \\
\text { 2016 }\end{array}$ & $\begin{array}{l}\text { Nested } \\
\text { PCR }\end{array}$ & $\begin{array}{l}\text { Pan } \\
\text { Loopamp } \\
\text { Malaria kit }\end{array}$ & $498(\mathrm{~s})$ & $\begin{array}{l}29(5.8) \\
\text { positive } \\
\text { for } \\
\text { P. ovale }\end{array}$ & 100 & 97.2 & 72.5 & 100 \\
\hline $\begin{array}{l}\text { Perera, } \\
2017 \text { [26] }\end{array}$ & UK & $\begin{array}{c}\text { Retrospective } \\
\text { (archived } \\
\text { WBS and } \\
\text { DBS)/ NR }\end{array}$ & $\begin{array}{l}\text { Nested } \\
\text { PCR }\end{array}$ & $\begin{array}{l}\text { In-house } \\
\text { high } \\
\text { throughput } \\
\text { (pan) LAMP }\end{array}$ & $699(\mathrm{~s})$ & $69(9.8)$ & $\begin{array}{l}97.1^{\#} \\
98.6^{\ddagger}\end{array}$ & $\begin{array}{l}100^{\#} \\
99.7^{\ddagger}\end{array}$ & $\begin{array}{l}100^{\#} \\
97.1^{\ddagger}\end{array}$ & $\begin{array}{l}99.7^{\#} \\
99.8^{\ddagger}\end{array}$ \\
\hline $\begin{array}{l}\text { Rypien, } \\
2017 \text { [27] }\end{array}$ & Canada & $\begin{array}{l}\text { Retrospective } \\
\text { (archived } \\
\text { WBS)/ } \\
\text { 2003-2014 }\end{array}$ & $\begin{array}{l}\text { Microscopy/ } \\
\text { RT-PCR } \\
\text { only for } \\
\text { discordant } \\
\text { results }\end{array}$ & $\begin{array}{l}\text { Illumigene } \\
\text { Malaria kit } \\
\text { Illumigene } \\
\text { Malaria Plus } \\
\text { kit }\end{array}$ & $140(\mathrm{~s})$ & $73(52.1)$ & $\begin{array}{l}97.3 \\
100\end{array}$ & $\begin{array}{l}93.8 \\
91.5\end{array}$ & $\begin{array}{l}45.2 \\
38.2\end{array}$ & $\begin{array}{l}99.8 \\
100\end{array}$ \\
\hline
\end{tabular}


Continue $\gg>$

\begin{tabular}{|c|c|c|c|c|c|c|c|c|c|c|}
\hline \multirow{2}{*}{$\begin{array}{l}\text { Author, } \\
\text { year of } \\
\text { publication } \\
\text { [reference] }\end{array}$} & \multirow[b]{2}{*}{ Country } & \multirow[b]{2}{*}{$\begin{array}{c}\text { Type/Period } \\
\text { of study }\end{array}$} & \multirow{2}{*}{$\begin{array}{l}\text { Reference } \\
\text { standard } \\
\text { method }\end{array}$} & \multirow[b]{2}{*}{$\begin{array}{l}\text { LAMP } \\
\text { assay type }\end{array}$} & \multirow{2}{*}{$\begin{array}{l}N^{\circ} \text { of } \\
\text { samples (s) } \\
\text { or patients } \\
\text { (p) tested }\end{array}$} & \multirow{2}{*}{$\begin{array}{l}N^{\circ}(\%) \\
\text { malaria } \\
\text { positive }\end{array}$} & \multicolumn{4}{|c|}{ Performance of LAMP assay } \\
\hline & & & & & & & $\begin{array}{c}\text { Sensitivity } \\
\%\end{array}$ & $\begin{array}{c}\text { Specificity } \\
\%\end{array}$ & $\begin{array}{c}P P V \\
\%\end{array}$ & $\begin{array}{c}N P V \\
\%\end{array}$ \\
\hline $\begin{array}{l}\text { De Koninck, } \\
2017 \text { [28] }\end{array}$ & Belgium & $\begin{array}{c}\text { Retrospective } \\
\text { (archived } \\
\text { WBS) + } \\
\text { prospective/ } \\
\text { Jun. 2015- } \\
\text { Jun. 2016 }\end{array}$ & $\begin{array}{l}\text { Microscopy/ } \\
\text { RDT/RT- } \\
\text { PCR }\end{array}$ & $\begin{array}{l}\text { Illumigene } \\
\text { Malaria kit }\end{array}$ & $\begin{array}{c}103(\mathrm{~s}) \\
+ \\
30(\mathrm{~s})\end{array}$ & $\begin{array}{c}66(64.1) \\
+ \\
11(36.6)\end{array}$ & $\begin{array}{l}100 \\
100\end{array}$ & $\begin{array}{l}100 \\
100\end{array}$ & $\begin{array}{l}\text { NR } \\
\text { NR }\end{array}$ & $\begin{array}{l}\text { NR } \\
\text { NR }\end{array}$ \\
\hline $\begin{array}{l}\text { Ponce, } \\
2017 \text { [29] }\end{array}$ & France & $\begin{array}{c}\text { Prospective / } \\
\text { Jun. 2016- } \\
\text { Jun. } 2017\end{array}$ & $\begin{array}{c}\text { Microscopy/ } \\
\text { RT-PCR }\end{array}$ & $\begin{array}{l}\text { Illumigene } \\
\text { Malaria } \\
\text { Plus kit }\end{array}$ & $310(\mathrm{~s})$ & $89(29.8)$ & 100 & 98.1 & 95.5 & 100 \\
\hline $\begin{array}{l}\text { Cheaveau, } \\
2017 \text { [30] }\end{array}$ & Canada & $\begin{array}{c}\text { Prospective / } \\
\text { Jun.2017- } \\
\text { Jan. } 2018\end{array}$ & $\begin{array}{l}\text { Microscopy/ } \\
\text { RT-PCR } \\
\text { only for } \\
\text { discordant } \\
\text { results }\end{array}$ & $\begin{array}{l}\text { Illumigene } \\
\text { Malaria kit }\end{array}$ & $348(s)$ & $86(22.8)$ & 100 & 100 & NR & NR \\
\hline $\begin{array}{l}\text { Frickmann, } \\
2017 \text { [31] }\end{array}$ & Germany & $\begin{array}{c}\text { Prospective } \\
\text { / Apr.-Dec. } \\
2017\end{array}$ & \begin{tabular}{|l} 
Microscopy/ \\
RT-PCR \\
only for \\
discordant \\
results
\end{tabular} & $\begin{array}{l}\text { Illumigene } \\
\text { Malaria kit }\end{array}$ & $1000(\mathrm{~s})$ & $238(23.8)$ & 98.7 & 99.6 & 98.7 & 99.6 \\
\hline $\begin{array}{l}\text { Kollenda, } \\
2018 \text { [32] }\end{array}$ & Germany & $\begin{array}{c}\text { Retrospective } \\
\text { (archived } \\
\text { WBS)/ } \\
\text { Apr.-Dec. } \\
2017\end{array}$ & $\begin{array}{l}\text { Microscopy+ } \\
\text { RT-PCR } \\
\text { only for } \\
\text { discordant } \\
\text { results }\end{array}$ & $\begin{array}{l}\text { In-house } \\
\text { LAMP } \\
\text { with genus } \\
\text { and species- } \\
\text { specific } \\
\text { primers }\end{array}$ & $523(\mathrm{~s})$ & $243(46.5)$ & $\begin{array}{l}96.3^{*} \\
71.0^{\S}\end{array}$ & $\begin{array}{l}98.9^{*} \\
90.8^{\S}\end{array}$ & $\begin{array}{l}\text { NR } \\
\text { NR }\end{array}$ & $\begin{array}{l}\text { NR } \\
\text { NR }\end{array}$ \\
\hline $\begin{array}{l}\text { Vincent, } \\
2018 \text { [33] }\end{array}$ & Japan & $\begin{array}{c}\text { Retrospective } \\
\text { (archived } \\
\text { WBS)/ } \\
\text { Jul.2011- } \\
\text { Dec. 2016 }\end{array}$ & Nested PCR & $\begin{array}{l}\text { Loopamp } \\
\text { Malaria } \\
\text { Pan/Pf kit, } \\
\text { Eiken }\end{array}$ & $117(\mathrm{~s})$ & $66(56.4)$ & $\begin{array}{l}96.9^{*} \\
97.8^{\S}\end{array}$ & $\begin{array}{l}100^{*} \\
100^{\S}\end{array}$ & $\begin{array}{l}\text { NR } \\
\text { NR }\end{array}$ & $\begin{array}{l}\text { NR } \\
\text { NR }\end{array}$ \\
\hline $\begin{array}{l}\text { Burdino, } \\
2019 \text { [34] }\end{array}$ & Italy & $\begin{array}{l}\text { Prospective } \\
\text { / Jan. 2017- } \\
\text { Dec. } 2018\end{array}$ & $\begin{array}{c}\text { Microscopy } \\
\text { +RT-PCR } \\
\text { only for } \\
\text { discordant } \\
\text { results }\end{array}$ & $\begin{array}{l}\text { Illumigene } \\
\text { Malaria kit }\end{array}$ & $478(\mathrm{p})$ & $76(15.9)$ & 100 & 100 & 100 & 100 \\
\hline $\begin{array}{l}\text { Hartmeyer, } \\
2019 \text { [18] }\end{array}$ & Denmark & $\begin{array}{l}\text { Prospective } \\
\text { / Sep. 2014- } \\
\text { May } 2017\end{array}$ & RT-PCR & $\begin{array}{l}\text { Illumigene } \\
\text { Malaria kit }\end{array}$ & $38(\mathrm{~s})$ & $28(73.7)$ & 96.4 & NR & NR & NR \\
\hline $\begin{array}{l}\text { Charpentier, } \\
2019 \text { [17] }\end{array}$ & France & $\begin{array}{l}\text { Prospective } \\
\text { / Aug. 2017- } \\
\text { Jan. } 2018\end{array}$ & qPCR & $\begin{array}{l}\text { Alethia } \\
\text { Malaria } \\
\text { kit (ex- } \\
\text { Illumigene } \\
\text { Malaria) }\end{array}$ & $331(\mathrm{p})$ & $73(22.5)$ & 97.3 & 99.6 & 94.8 & 99.8 \\
\hline Total samples & & & & & 6289 & $\begin{array}{c}1663 \\
(26.4 \%)\end{array}$ & & & & \\
\hline
\end{tabular}

WBS, whole blood samples; DBS, dried blood spots; PCR, polymerase chain reaction; RT-PCR, real time-PCR; PET, photoinduced electron transfer; qPCR, quantitative PCR; PPV, positive predictive value; NPV, negative predictive value; NR, not reported.

"Plasmodium species; ${ }^{P}$ P. falciparum; ${ }^{*} \mathrm{WBS}$; ${ }^{\mathrm{D} D \mathrm{DS}}$. 
centres, and the remaining in Denmark, Italy, Switzerland and The Netherlands) [17-21, 24-26, $28-32,34]$. Four studies were conducted in North America ( 3 in Canada and 1 in the USA) and one in Japan [22, 23, 27, 30, 33]. Fourteen studies employed a commercial LAMP assay (Loopamp ${ }^{\mathrm{TM}}$ Malaria Pan/Pf, Eiken Chemical, Japan, in five cases and Illumigene Malaria ${ }^{\circledR}$, Meridian Bioscience, Cincinnati, $\mathrm{OH}$, USA [now Alethia] in 9 cases) [17-19, 21, 23-25, 27-31, 33, 34]. An in-house LAMP was adopted in other 4 studies [20, 22, 26, 32]. The performance of LAMP was compared to standard microscopy in 15 studies, RDTs in 8, quantitative buffy coat (QBC) in 1. All the studies adopted a PCR technique as standard reference method to confirm malaria diagnosis or to solve discordant results between LAMP and microscopy/RDT.

\section{Performance of LAMP}

Data regarding the performance of LAMP across the studies are shown in Table 1. The sensitivity of commercial LAMP tests (either Eiken or Illumigene) ranged between $96.4 \%$ and $100 \%$, and the specificity between $93.8 \%$ and $100 \%[17,18,20,21$, 23-25, 27-31, 33, 34]. In five studies both sensitivity and specificity were reported to be $100 \%$ [21, $24,28,30,34]$. The sensitivity of in-house LAMP assays ranged from $93.9 \%$ to $100 \%$, with three out of four studies showing a sensitivity below $97.1 \%$ and the specificity was $100 \%$ in all of the studies except one $[19,26,32]$.

Positive predictive value (PPV) and negative predictive value (NPV) were reported by ten studies. $[17,20,21,25-27,29-31,34]$ In eight of these studies the PPV varied from $92.7 \%$ to $100 \%$, but in the study by Rypien et al. it was of $45.2 \%$ and in the study by Cuadros et al. that only included samples positive for P. ovale malaria it was of $72.5 \%$ [27, 25]. The NPV value ranged from $99.6 \%$ to $100 \%$ across the studies [17, 20, 21, 25-27, 29, 31, 34].

Five studies evaluated a LAMP assay with targets specific for $P$. falciparum $[19,20,23,32$, 33]. In three of these studies in which a commercial LAMP able to identify P. falciparum (Eiken Chemical, Japan) was used, the sensitivity ranged between 97.6 and $98.4 \%$ and the specificity between 98.1 and $100 \%$ [20, 23, 33]. Two studies that employed an in-house LAMP targeting the mitochondrial sequence $P g M t 19$ showed a lower sensitivity: $71 \%$ and $93.9 \%$, respectively $[19,32]$.
Comparison of accuracy of LAMP respect to microscopy and rapid diagnostic tests

Data on the accuracy of LAMP assay in detecting malaria positive samples as compared to conventional methods (microscopy \pm RTD) are shown in Table 2.

LAMP showed to perform better than microscopy in $10 / 15$ studies $(66.7 \%)$ and equally to microscopy in four other studies, with only Rypien et al. reporting a lower performance of LAMP compared to microscopy [17-21, 23, 24, 27-34] . Two studies reported detailed data on the accuracy of thin and thick smear in comparison with LAMP $[18,34]$. In the study by Burdino et al. the sensitivity of LAMP was $100 \%$ as compared to $94.7 \%$ for thin smear (TnS) and $97.4 \%$ for thick smear (TkS), and in the study by Charpentier et al the values were $97.3 \%, 84.9 \%, 86.3 \%$, respectively [34, 17].

LAMP performed better than RDTs in all the eight studies in which the two methods were compared $[17,18,23,24,28,30,33,34]$. In the study by De Koninck et al. LAMP performed in the same way of RDT in the retrospective arm whereas was better in the prospective arm [28]. One study also showed a higher accuracy of LAMP respect to quantitative buffy coat (QBC) [17].

\section{Limits of detection of LAMP}

In the study by Polley et al. the LAMP based on primer sets targeting mitochondrial DNA was tested against both purified DNA from the WHO international $P$. falciparum standard and archived blood samples representing different Plasmodium species infections, and results showed a limit of detection (LoD) of LAMP of 5 parasite genome equivalents for 3 species ( $P$. malariae, P. ovale, P. vivax) and of 2 parasite genome equivalents for $P$. falciparum [19]. Lucchi et al. using a malachite-green (MG)-based LAMP consistently detected samples with as low as 1 parasites $/ \mu \mathrm{L}$ for $P$. vivax, 4 parasites $/ \mu \mathrm{L}$ for $P$. falciparum and $P$. ovale and 8 parasites $/ \mu \mathrm{L}$ for $P$. malariae, without loss of performance when filter papers were used instead of fresh blood samples [22]. Another study that tested the Loopamp Pan/ Pf Malaria kit coupled with either a PCR thermo-cycler and a non-instrumented nucleic acid amplification (NINA) platform heater, found a LoD of 5 parasites $/ \mu \mathrm{L}$ and of 1 parasite $/ \mu \mathrm{L}$ for $P$. vivax [23]. The same LAMP kit combined with an ultra-rapid extraction method resulted in a LoD of 1 parasite/ $\mu \mathrm{L}$, and when used on only P. ovale 
Table 2 - Accuracy of Loop-mediated isothermal amplification (LAMP) assay in detecting malaria positive samples as compared to conventional methods.

\begin{tabular}{|c|c|c|c|c|c|c|}
\hline Author [reference] & $\begin{array}{l}N^{\circ} \text { of samples } \\
\text { tested }\end{array}$ & $\begin{array}{l}N^{\circ} \text { of confirmed malaria } \\
\text { positive samples }\end{array}$ & $\begin{array}{c}\text { LAMP positive } \\
N^{\circ}(\%)\end{array}$ & $\begin{array}{c}\text { Microscopy positive } \\
N^{\circ}(\%)\end{array}$ & $\begin{array}{c}\text { RDT positive } \\
N^{\circ}(\%)\end{array}$ & $\begin{array}{c}\text { QBC positive } \\
N^{\circ}(\%)\end{array}$ \\
\hline Polley [19] & 143 & 33 & 31 (93.9) & 31 (93.9) & ND & ND \\
\hline Polley [20] & 705 & 67 & $65(97.0)$ & $56(83.6)$ & ND & ND \\
\hline Marti [21] & 205 & (47) & $47(100)$ & $43(91.5)$ & ND & ND \\
\hline Mohon [23] & 140 & 71 & $72(100)^{*}$ & 69 (97.2) & $61(85.9)$ & ND \\
\hline Rypien [27] & 140 & 76 & $73(96.0)$ & $76(100)$ & ND & ND \\
\hline De Koninck [28] & $\begin{array}{c}103 \\
30\end{array}$ & $\begin{array}{l}74 \\
12\end{array}$ & $\begin{array}{l}74(100) \\
12(100)\end{array}$ & $\begin{array}{l}74(100) \\
11(91.7)\end{array}$ & $\begin{array}{c}74(100) \\
9(75)\end{array}$ & $\begin{array}{l}\text { ND } \\
\text { ND }\end{array}$ \\
\hline Ponce [29] & 299 & 89 & $93(100)^{*}$ & $83(93.2)$ & ND & ND \\
\hline Van Gool [24] & 273 & 85 & $\begin{array}{l}84(98.8)^{\mathrm{a}} \\
85(100)^{\mathrm{b}}\end{array}$ & $85(100)$ & $76(89.4)$ & ND \\
\hline Cheavenau [30] & 377 & 57 & $57(100)$ & $51(89.5)$ & ND & ND \\
\hline Frickmann [31] & 1000 & 107 & $106(99.1)$ & $99(92.5)$ & ND & ND \\
\hline Kollenda [32] & 523 & 243 & $234(96.3)$ & $173(71.2)$ & ND & ND \\
\hline Vincent [33] & 117 & 66 & $64(96.9)$ & $62(93.9)$ & $58(87.9)$ & ND \\
\hline Burdino [34] & 478 & 76 & $76(100)$ & $\begin{array}{c}72(94.7)^{\wedge} \\
74(97.4)^{\#}\end{array}$ & 74 (97.4) & ND \\
\hline Hartmeyer [18] & 38 & 28 & 27 (96.4) & $17(60.7)$ & $17(60.7)$ & ND \\
\hline Charpentier [17] & 331 & 73 & $71(97.3)$ & $\begin{array}{l}62(84.9)^{\wedge} \\
63(86.3)^{\#}\end{array}$ & $63(86.3)$ & $63(86.3)$ \\
\hline Total & 4902 & 1200 & $1182(98.5)$ & 1064 (88.7) & $432(89.1)$ & $63(86.3)$ \\
\hline
\end{tabular}

RDT, rapid diagnostic tests; $\mathrm{QBC}$, Quantitative Buffy Coat; * One or more false positive results, alllumigene Malaria; ${ }^{\mathrm{b}}$ Illumigene Malaria Plus; ${ }^{\wedge}$ Thin smear; "Thick smear; ND, not done.

infection samples showed to detect 0.8-2 parasite $/ \mu \mathrm{L}[33,25]$. Perera et al. using a pan-LAMP coupled with a high throughput sample processing system found a single false-negative result in a whole blood sample containing $<1$ parasite $/ \mu \mathrm{L}$ and 2 false negative results in dried blood spots containing $<1$ parasite $/ \mu \mathrm{L}$ [26]. This study also found that the mean time to turbidity ranged from 17.5 minutes when parasitaemia was $10.000 / \mu \mathrm{L}$ to 22.9 minutes when it was 1 parasite / $\mu \mathrm{L}$ [26]. The analytical sensitivity of the Illumigene ${ }^{\circledast}$ Malaria kit was of 0.5 parasite $/ \mu \mathrm{L}$ for both $P$. falciparum and $P$. vivax in the study by De Koninck et al. [28], and that of the Illumigene Malaria Plus was of 0.1 parasite $/ \mu \mathrm{L}$ in the study by Ponce et al. [29].

\section{Malaria species identification}

Four studies employing the commercial Loopamp Malaria Pan/Pf (Eiken Chemical, Japan) were able to identify $P$. falciparum with a sensitivity ranging from $97.6 \%$ to $100 \%$ and a specificity ranging from
$98.1 \%$ to $100 \%$ [20, 21, 23, 33]. Kollenda et al. using an in-house species-specific malaria LAMP found a sensitivity and specificity for $P$. falciparum respectively of $71 \%$ and $90.8 \%$ for fresh blood samples, and of $92.0 \%$ and $99.1 \%$ for haemolytic blood samples; however, the sensitivity resulted poor when $P$. falciparum parasitaemia was lower than 50 parasites $/ \mu \mathrm{L}$ [32]. The authors also found that the sensitivity and specificity of $P$. vivax-specific LAMP decreased when fresh blood samples were used instead of haemolytic blood samples $(82.4 \%$ vs $100 \%$ and $95.3 \%$ vs $100 \%$, respectively); moreover, both $P$. ovale and P. malariae-specific LAMP showed a $100 \%$ sensitivity, but the specificity was lower for P. ovale than P. malariae (95 vs $98.8 \%$ ) although the tested sample was small [32].

\section{LAMP invalid or discordant results}

A total of 12 studies reported data on the frequency of invalid results from LAMP and discordant results between LAMP and reference methods 
Table 3 - Frequency of invalid results and discrepancies between Loop-mediated isothermal amplification (LAMP) and reference methods.

\begin{tabular}{|c|c|c|c|c|c|c|c|}
\hline \multirow[b]{2}{*}{$\begin{array}{l}\text { Author } \\
\text { [reference] }\end{array}$} & \multirow[b]{2}{*}{ Type of LAMP } & \multirow[b]{2}{*}{$\begin{array}{l}\text { Reference } \\
\operatorname{method}(s)\end{array}$} & \multicolumn{2}{|c|}{ Initial analysis } & \multicolumn{2}{|c|}{ Secondary analysis* } & \multirow[b]{2}{*}{ Comments } \\
\hline & & & $\begin{array}{l}\text { Discordant } \\
\text { results, } n^{\circ} \\
(\%)\end{array}$ & $\begin{array}{l}\text { Invalid } \\
\text { results } \\
n^{\circ}(\%)\end{array}$ & $\begin{array}{l}\text { Discordant } \\
\text { results, } n^{\circ} \\
(\%)\end{array}$ & $\begin{array}{l}\text { Invalid } \\
\text { results } \\
n^{\circ}(\%)\end{array}$ & \\
\hline $\begin{array}{l}\text { Polley } \\
{[20]}\end{array}$ & $\begin{array}{l}\text { In-house } \\
\text { Pan- and } \\
\text { Pf- specific }\end{array}$ & Nested-PCR & $15(2.1)$ & NR & $11(1.6)$ & NR & $\begin{array}{l}11 \text { false positive LAMP-results, } \\
\text { of which } 5(45.5 \%) \text { were attributable to } \\
\text { temporary laboratory contamination }\end{array}$ \\
\hline $\begin{array}{l}\text { Lucchi } \\
\text { [22] }\end{array}$ & $\begin{array}{l}\text { Loopamp } \\
\text { Malaria Pan/ } \\
\text { Pf kit }\end{array}$ & RT-(PET) PCR & $3(1.6)$ & $1(0.5)$ & - & - & $\begin{array}{l}3 \text { undetermined results, of which } \\
2 \text { attributable to very low parasite } \\
\text { density }(2 / \mu \mathrm{L})\end{array}$ \\
\hline $\begin{array}{l}\text { Mohon } \\
\text { [23] }\end{array}$ & $\begin{array}{l}\text { Loopamp } \\
\text { Malaria Pan/ } \\
\text { Pf kit }\end{array}$ & $\begin{array}{l}\text { Microscopy + } \\
\text { nested PCR }\end{array}$ & $\begin{array}{c}6(4.3)^{\wedge} \\
5(3.6 \%)^{\S}\end{array}$ & NR & $\begin{array}{l}3(2.1)^{\wedge} \\
3(0.7)^{\S}\end{array}$ & NR & $\begin{array}{l}2 \text { false positive P. falciparum results } \\
\text { in both the two type of LAMP used }\end{array}$ \\
\hline $\begin{array}{l}\text { Rypien } \\
\text { [27] }\end{array}$ & $\begin{array}{l}\text { Illumigene } \\
\text { Malaria and } \\
\text { Malaria plus } \\
\text { kit }\end{array}$ & Microscopy & $\begin{array}{l}6(4.3)^{\#} \\
5(3.8)^{\dagger}\end{array}$ & $\begin{array}{l}1(<0.01)^{\#} \\
8(5.7)^{+}\end{array}$ & $\begin{array}{c}0(0)^{\#} \\
1(0.7)^{\dagger}\end{array}$ & $\begin{array}{c}1(<0.01)^{\#} \\
1(0.7)^{\dagger}\end{array}$ & $\begin{array}{l}\text { All discordant results involving the } \\
\text { M kit" were solved in favour of LAMP } \\
\text { ( } 5 \text { true positive and } 1 \text { true negative), and } \\
\text { the same was for } 4 \text { discordant obtained } \\
\text { by the MP kit }{ }^{+} ; 1 \text { invalid result for each } \\
\text { of the two tests remained unsolved. }\end{array}$ \\
\hline $\begin{array}{l}\text { De Koninck } \\
\text { [28] }\end{array}$ & $\begin{array}{l}\text { Illumigene } \\
\text { Malaria kit }\end{array}$ & $\begin{array}{l}\text { Microscopy+ } \\
\text { RDT+PCR }\end{array}$ & $1(3.3)$ & $0(0)$ & - & - & $\begin{array}{l}1 \text { discordant result (RDT and LAMP } \\
\text { positive/microscopy negative) was } \\
\text { not solved by PCR because no left-over } \\
\text { blood was available }\end{array}$ \\
\hline $\begin{array}{l}\text { Ponce } \\
{[29]}\end{array}$ & $\begin{array}{l}\text { Illumigene } \\
\text { Malaria Plus } \\
\text { kit }\end{array}$ & $\begin{array}{l}\text { Microscopy+ } \\
\text { PCR }\end{array}$ & $4(1.3)$ & $11(3.5)$ & - & - & $\begin{array}{l}4 \text { false positive LAMP-results were } \\
\text { attributed to laboratory contamination; } \\
11 \text { invalid results ( } 4 \text { pos. and } 7 \text { neg.) } \\
\text { remained unsolved }\end{array}$ \\
\hline $\begin{array}{l}\text { Cheaveau } \\
\text { [30] }\end{array}$ & $\begin{array}{l}\text { Illumigene } \\
\text { Malaria kit }\end{array}$ & $\begin{array}{l}\text { Microscopy+ } \\
\text { PCR }\end{array}$ & $8(2.1)$ & $12(3.2)$ & $0(0)$ & $0(0)$ & $\begin{array}{l}\text { All the } 8 \text { discordant results resolved } \\
\text { in favour of LAMP ( } 7 \text { true positive } \\
\text { and } 1 \text { true negative) }\end{array}$ \\
\hline $\begin{array}{l}\text { Frickmann } \\
{[31]}\end{array}$ & $\begin{array}{l}\text { Illumigene } \\
\text { Malaria kit }\end{array}$ & $\begin{array}{l}\text { Microscopy+ } \\
\text { PCR }\end{array}$ & $6(0.07)$ & NR & - & - & $\begin{array}{l}3 \text { false positive and } 3 \text { false negative } \\
\text { LAMP- results, the latter attributed } \\
\text { to low-levels parasitaemia ( } 2 \text { patients } \\
\text { were under treatment) }\end{array}$ \\
\hline $\begin{array}{l}\text { Vincent } \\
{[33]}\end{array}$ & $\begin{array}{l}\text { Loopamp } \\
\text { Malaria Pan/ } \\
\text { Pf kit }\end{array}$ & Nested-PCR & $2(1.7)$ & NR & - & - & $\begin{array}{l}\text { Pan- and Pf-LAMP missed } 1 \\
\text { P. ovale and } 1 \text { P. falciparum diagnoses, } \\
\text { respectively }\end{array}$ \\
\hline $\begin{array}{l}\text { Burdino } \\
{[34]}\end{array}$ & $\begin{array}{l}\text { Illumigene } \\
\text { Malaria kit }\end{array}$ & $\begin{array}{l}\text { Microscopy, } \\
\text { RDT }\end{array}$ & $2(0.4)$ & NR & $0(0)$ & NR & $\begin{array}{l}2 \text { discrepancies resolved to be true } \\
\text { positive LAMP-results: in these cases, } \\
\text { malaria could be identified } 1 \text { day } \\
\text { earlier than microscopy and RDT }\end{array}$ \\
\hline $\begin{array}{l}\text { Hartmeyer } \\
{[18]}\end{array}$ & $\begin{array}{l}\text { Illumigene } \\
\text { Malaria kit }\end{array}$ & $\begin{array}{l}\text { Microscopy, } \\
\text { RDT, PCR }\end{array}$ & $1(2.6)$ & NR & - & - & $\begin{array}{l}1 \text { false negative result in a patient } \\
\text { recently treated for } P \text {. falciparum having } \\
\text { low-level parasitaemia }\end{array}$ \\
\hline $\begin{array}{l}\text { Charpentier } \\
\text { [17] }\end{array}$ & $\begin{array}{l}\text { Alethia } \\
\text { Malaria kit } \\
\text { (ex-Illumigene } \\
\text { Malaria) }\end{array}$ & $\begin{array}{l}\text { Microscopy/ } \\
\text { RDT,/QBC+ } \\
\text { qPCR }\end{array}$ & $3(0.9)$ & $11(3.3)$ & 2 & $2(0.6)$ & $\begin{array}{l}2 \text { false negative results attributable } \\
\text { to very low parasite load }\end{array}$ \\
\hline
\end{tabular}

${ }^{*}$ PCR testing or re-testing and/or LAMP re-testing; ${ }^{\wedge}$ Non-instrumented nucleic acid amplification (NINA)-LAMP; §Thermocycler-LAMP; "Illumigene Malaria kit ; +Illumigene Malaria Plus kit. 
adopted and attempts to solve them (Table 3) [17, 18, 20, 22, 23, 27-34].

In the study by Polley et al. 15/143 (2.1\%) samples were positive at Loopamp Malaria Pan/Pf assay but negative at the nested-PCR in the initial analysis, but re-testing resulted in 11 actual discrepancies $(1.6 \%)$ almost half of whom were false positive LAMP-results attributable to a later discovered 10-day period of laboratory contamination [20]. By re-testing initial mismatching results, Mohon et al. confirmed three discordant results between Loopamp Malaria Pan/Pf and nested-PCR (2.1\% for Pan-LAMP and $0.7 \%$ for Pf-LAMP), including 2 false positive $P$. falciparum results [23]. Using the same LAMP assay, Vincent et al. found 2 discordant results, with LAMP missing to detect $P$. falciparum and $P$. ovale in two patients with a history of recent anti-malarial therapy [33].

Rypien et al. obtained invalid results (i.e., empty well or instrument error) in $5.7 \%$ of samples tested with Illumigene Malaria Plus and in $<0.01 \%$ of those tested with the Illumigene Malaria [27]. When testing was repeated on new fresh specimen aliquots, 7 invalid results were solved, leaving an invalid rate of 1 in $140(<0.01 \%)$ for both the assays. In the same study, 6 results from Illumigene $\mathrm{M}$ and 4 from Illumigene MP disagreed with related microscopy results, but an in-house quantitative PCR testing solved discrepancies in favour of LAMP Illumigene $\mathrm{M}$ in all the cases, whereas one false positive and two false negative from LAMP Illumigene MP were confirmed [27]. In the prospective evaluation conducted by De Koninck et al. one discordant result (1/30, 3.3\%) between Illumigene $\mathrm{M}$ and microscopy was observed but the absence of left-over blood samples prevented a secondary analysis [28]. In the study by Ponce et al. the Illumigene MP gave 11 (3.5\%) invalid results and four discrepant positive results (possibly due to contaminations), but a re-testing was not performed [29]. A similar rate of initial invalid results $(3.2 \%)$ was observed by Chevenau et al. which were all solved with a single repeat testing; moreover, all of the 8 discrepant results obtained in the initial analysis were solved in favour of LAMP (7 true positive and one true negative) [30].

In the study by Burdino et al, positive results from the Illumigene Malaria kit disagreed with negative results from conventional microscopy+RDT in two patients subsequently diagnosed with ma- laria by RT-PCR [34]. A single discordant result between Illumigene Malaria and RT-PCR was detected by Hartmeyer in a sample from a patient who had received treatment for $P$. falciparum infection before testing showing a weak positivity at RT-PCR; however, the repeat of LAMP testing gave a positive result [18]. Finally, in the study by Charpentier and co-workers, the Alethia malaria kit (ex-Illumigene Malaria) resulted in 11 invalid results $(3.3 \%)$ at the initial analysis, but 9 of them were solved after a repeat testing; the secondary analysis confirmed two false negative LAMP-results on samples with very low parasitaemia [17].

\section{DISCUSSION}

A rapid and accurate malaria diagnosis can be a challenge in several countries where the disease is not endemic especially when well-trained expert microscopists are lacking. Starting from the early 2000 s the LAMP assay, a novel nucleic acid amplification method which combines several important advantages (i.e., easy to perform, rapid, reliable, cost-effective) was increasingly used for diagnosis of infectious diseases [35]. LAMP is an isothermal reaction $\left(60-65^{\circ} \mathrm{C}\right)$ that relies on the Bacillus stearothermophilus enzyme which does not require technical support for cyclical temperature change procedures thus being valuable as a point-of-care use either in endemic and non-endemic setting [36]. The results of LAMP reaction can be visualized or detected by turbidimetry, bioluminescent (fluorescence) output or using non-instrumented nucleic acid amplification platforms [22, 37-39]. The first study employing a LAMP assay for $P$. falciparum was published in 2006 showing 95\% sensitivity and $99 \%$ specificity when compared with PCR as reference method [40]. Initially, genus- and species-specific LAMP primers were designed to target the highly conserved $18 \mathrm{~S}$ ribosomal RNA genes of the four human malaria Plasmodium species $[40,41]$. Subsequently, a LAMP assay targeting mitochondrial DNA of P. falciparum and of Plasmodium genus showed a better sensitivity with the capacity to detect as few as five parasites per $\mu \mathrm{L}$ of blood [19]. At present, two clinically validated and CE marked LAMP kits are available, one pan-genus Plasmodium specific (Alethia, ex-Illumigene) LAMP Malaria, Meridian, Cincinnati, $\mathrm{OH}, \mathrm{USA}$ ) and the other one combining pan-genus and P. falciparum specific assays (Loopamp ${ }^{\mathrm{TM}}$ Malaria Pan 
and Malaria Pf, Eiken Chemical, Tokyo, Japan) [17, 18, 20, 21, 23-25, 27-31, 33, 34]. Moreover, a new $P$. vivax-specific LAMP assay kit has been recently released into the market (Loopamp ${ }^{\mathrm{TM}}$ Malaria PV, Eiken Chemical, Tokyo, Japan).

In our review regarding the use of LAMP for malaria diagnosis in non-endemic countries we found that the majority of studies were published between 2017 and 2020 demonstrating an increase interest for the use of this diagnostic method [17, 18, 24-34].

With the exception of the study by Polley et al. published in 2010, all the studies showed an excellent sensitivity (96-100\%) and specificity (99.6$100 \%)$ [17, 18, 20-34].

Overall, 6259 samples were evaluated across the eighteen studies with 1663 confirmed malaria diagnosis by the reference method; considering only the fifteen studies which compared LAMP with microscopy and/or RDTs the global sensitivity of LAMP was $98.5 \%$ with both the above-mentioned methods unable to recognize about $10 \%$ of malaria infections (Table 2). For P. falciparum malaria diagnosis, the commercial LAMP performed better than in-house LAMP with sensitivity ranging from $97.6 \%$ to $100 \%$ and specificity from $98.1 \%$ to $100 \%$ [19-21, 23, 32, 33]. In the study by Polley et al. using primers targeting mitochondrial DNA of P. falciparum (PgMt869) the sensitivity of the assay was $93.3 \%$ with $100 \%$ specificity, a result not different from that obtained in the same study with the pan-genus primers. [19]. Indeed, in the study by Kollenda et al. the designed primers for $P$. falciparum directed against the histone deacetylase gene sal-1 had a very poor performance with an overall sensitivity of $71 \%$ being disappointingly low $(50 \%)$ for samples with parasitaemia $\leq 50 / \mu \mathrm{L}$ [32]. Interestingly, in the only study in whom only predetermined $P$. ovale positive samples were tested with one of the commercially available pan-genus LAMP, the sensitivity was $100 \%$ with a specificity of $97.2 \%$ and the limit of detection was between 0.8 and 2 parasite/ $\mu \mathrm{L}$ [25]. Overall, the limit of detection of malaria parasites using the commercially available LAMP assays was very low (equal or under 5 parasites $/ \mu \mathrm{L}$ ) which is better than the best LOD obtained by an expert microscopist or by RDT tests $[6,17,25,28,29,33]$. Considering the very high negative predictive value of the LAMP assay (ranging from $99.6 \%$ to $100 \%$ ) together with the high sensitivity it has been proposed by several authors to change the algorithm for malar- ia diagnosis among febrile travellers adopted in most laboratories (i.e., initial thick and thin film microscopy and/or RDT and repeating thick and thin film microscopy on negatives) adopting only pan-genus LAMP as the screening test to rule out malaria infection $[17,18,27,28,30,34]$. According$1 \mathrm{y}$, a negative LAMP assay should not be followed as actually required after an initial negative blood microscopy by the need to repeat blood examination to rule out malaria. However, the LAMP assay due to its qualitative response (i.e., no species identification and no information about parasitaemia) cannot stand alone and needs to be followed by blood microscopy to identify the Plasmodium species and to quantify parasite density. In the study by Charpentier et al. the most sensitive strategy using a combination of two tests performed simultaneously resulted to be LAMP plus thin smear $(97.3-100 \%)$ and RDT plus thin smear $(95.9-100 \%)$ [17]. However, it should be highlighted that blood microscopy examination is of paramount importance to identify other microorganisms responsible of febrile syndrome that will be otherwise missed among returning travellers or migrants [42-44]. Discordant results between the LAMP and the adopted reference method for the diagnosis of malaria were reported on initial analysis in 0.07 to $4.3 \%$ of cases but the mismatch was solved in the majority of cases leaving only few discordant results mainly attributable to laboratory contamination (Table 3) $[18,20,22,23,27-31,33$, 34]. Five studies recorded invalid (uninterpretable) results with rates ranging from $<0.01$ to $5.7 \%$. $[17,22,27$, $29,30]$. Such invalid results need to be repeated and the second round of LAMP was able to solve it in the majority of cases except in the study by Ponce et al. in which also a second attempt gave an invalid result [29]. In the only study in whom a cost analysis was performed, the implementation of LAMP as initial screening with subsequent RDT and blood microscopy employed only for positive samples a cost saving of 13.2 US\$ per malaria test was calculated against the usual workflow requiring repetition of blood microscopy at least 2-3 times following the first negative result [27].

In conclusion, the pan-genus LAMP assay showed high sensitivity and specificity and a very high negative predictive value together with a limit of detection of Plasmodium parasites that would indicate it as the best initial screening test to be used for malaria diagnosis in a non-endemic setting. 
However, pan-genus LAMP would be a suitable method also for screening in malaria endemic areas preventing the over-treatment for malaria by rule out this diagnosis when the test shows a negative result. In this regard, a meta-analysis regarding LAMP diagnostic accuracy of uncomplicated malaria diagnosis in endemic areas showed an excellent accuracy range and suggested its potential use in rural health clinic as a tool in malaria control/elimination programmes [45].

In all the studies conducted so far in Europe and North America, LAMP performed better than blood microscopy and RDTs for malaria diagnosis with a comparable sensitivity to RT-PCR. However, LAMP cannot stand alone and must be associated with another method (thin/thick blood smear \pm RDTs) for species identification and quantification of positive samples.

\section{Declaration of competing interest}

The authors have no relevant financial involvement with any organization with a financial interest with the subject matter or materials discussed in the manuscript.

\section{Acknowledgments}

We thank Dr. Carlo Parravicini for helpful comments.

\section{Author contributions}

All authors read and approved the final version of the manuscript.

Spinello Antinori and Anna Lisa Ridolfo conceived the study, reviewed the literature and wrote the final manuscript. Romualdo Grande, Laura Galimberti, Giacomo Casalini, Andrea Giacomelli and Laura Milazzo reviewed the literature, analysed data and contributed to the writing of the manuscript.

\section{Funding \\ This paper was not funded}

\section{REFERENCES}

[1] Antinori S, Galimberti L, Giannelli E, et al. Prospective observational study of fever in hospitalized returning travellers and migrants from tropical areas, 19972001. J Travel Med. 2004; 11, 135-42.

[2] Wilson ME, Weld LH, Boggild A, et al. Fever in returned travellers: results from the GeoSentinel Surveillance Network. Clin Infect Dis. 2007; 44, 1560-8.
[3] WHO. World malaria report 2020: 20 years of global progress and challenge. Geneva, World Health Organization, 2020.Licence: CC BY-NC-SA 3.0 IGO.

[4] European Centre for Disease Prevention and Control. Malaria. In: ECDC. Annual epidemiological report for 2018. Stockholm: ECDC; 2020.

[5] Mace KE, Lucchi NW, Tan KR. Malaria surveillanceUnited States, 2017. MMWR. 2021; 70 (2), 1-35.

[6] Garcia LS. Malaria update for the clinical microbiology laboratory: a new species, Plasmodium knowlesi, and new diagnostic tests. Clin Microbiol Newsletter. 2010; 32, 127-33.

[7] Hanscheid T, Melo-Cristino J, Pinto BG. Automated detection of malaria pigment in white blood cells for the diagnosis of malaria in Portugal. Am J Trop Med Hyg. 2001; 64, 290-2.

[8] Chilton D, Malik AN, Armstrong M, Kettelhut M, Parker-Williams J, Chiodini PL. Use of rapid diagnostic tests for diagnosis of malaria in the UK. J Clin Pathol. 2006; 59, 862-6.

[9] Vernelen K, Barbé B, Gillet P, Van Esbroeck M, China B, Jacobs J. Photo-based external quality assessment of malaria rapid diagnostic tests in a non-endemic setting. PloS One. 2018; 13 (8), e0201622.

[10] Orish VN, De-Gaulle VF, Sanyaolu AO. Interpreting rapid diagnostic test (RDT) for Plasmodium falciparum. BMC Research Notes. 2018; 11, 850.

[11] Hanscheid T, Grobusch MP. How useful is PCR in the diagnosis of malaria? Trends Parasitol. 2002; 18, 395-8. [12] Chiodini PL. LAMP in the context of travellers'malaria: a shining light? Travel Med Infect Dis. 2015; 13, 126-7. [13] Yerlikaya S, Campillo A, Gonzalez IJ. A systematic review: performance of rapid diagnostic tests for the detection of Plasmodium knowlesi, Plasmodium malariae, and Plasmodium ovale monoinfections in human blood. J Infect Dis. 2018; 218, 265-76.

[14] Antinori S, Piazza M, Calattini S, et al. Subacute malaria due to Plasmodium falciparum and the role of polymerase chain reaction. Clin Infect Dis. 2001; 33, 1614-5.

[15] Berry A, Benoit-Vical F, Fabre R, Cassaing S, Magnaval JF. PCR-based methods to the diagnosis of imported malaria. Parasite. 2008; 15, 484-8.

[16] Nijhuis RHT, van Lieshout L, Verweij JJ, Claas ECJ, Wessels E. Multiplex real-time PCR for diagnosing malaria in a non-endemic setting: a prospective comparison to conventional methods. Eur J Clin Microbiol Infect Dis. 2018 ; 37, 2323-9.

[17] Charpentier E, Benichou E, Pages A, et al. Performance evaluation of different strategies based on microscopy techniques, rapid diagnostic test and molecular loop-mediated isothermal amplification assay for the diagnosis of imported malaria. Clin Microbiol Infect. 2020; 26, 115-21.

[18] Hartmeyer GN, Hoegh SV, Skov MN, Kemp M. Use of loop-mediated isothermal amplification in a resource-saving strategy for primary malaria screening 
in a non-endemic setting. Am J Trop Med Hyg. 2019; 100, 566-71.

[19] Polley SD, Mori Y, Watson J, et al. Mitochondrial DNA targets increase sensitivity of malaria detection using loop-mediated isothermal amplification. J Clin Microbiol. 2010; 48, 2866-71.

[20] Polley SD, Gonzalez IJ, Mohamed D, et al. Clinical evaluation of a loop-mediated amplification kit for diagnosis of imported malaria. J Infect Dis. 2013; 208, 637-44. [21] Marti H, Stalder C, Gonzalez IJ. Diagnostic accuracy of a LAMP kit for diagnosis of imported malaria in Switzerland. Travel Med Infect Dis. 2015; 13, 167-71.

[22] Lucchi NW, Ljolje D, Silva-Flannery L, Udhayakumar V. Use of malachite green-loop mediated isothermal amplification for detection of Plasmodium spp. parasites. Plos One 2016; 11: e0151437.

[23] Mohon AN, Da-Yeong Lee L, Bayih AG et al. NINA-LAMP compared to microscopy, RDT, and nested PCR fort the detection of imported malaria. Diagn Microbiol Infect Dis. 2016; 85, 149-53.

[24] Van Gool T, Verhaar N, Wentink E et al. The Illumigene ${ }^{\circledR}$ malaria and Illumigene malaria plus assays: new and highly effective screening tools for malaria in western laboratory settings. $2^{\text {th }}$ ECCMID, Vienna 22-25 April 2017, OS0857.

[25] Cuadros J, Martin Ramirez A, Gonzalez IJ, et al. LAMP kit for diagnosis of non-falciparum malaria in Plasmodium ovale infected patients. Malar J. 2017; 16, 20.

[26] Perera RS, Ding XC, Tully F, et al. Development and clinical performance of high throughput loop-mediated isothermal amplification for detection of malaria. Plos One. 2017; 12 (2): e0171126.

[27] Rypien C, Chow B, Chan WW, Church DL, Pillai DR. Detection of Plasmodium infection by the illumigene malaria assay compared to reference microscopy and real-time PCR. J Clin Microbiol. 2017; 55, 3037-45.

[28] De Koninck A-S, Cnops L, Hofmans M, Jacobs J, Van den Bossche D, Philippé J. Diagnostic performance of the loop-mediated isothermal amplification (LAMP) based Illumigene ${ }^{\circledR}$ malaria assay in a non-endemic region. $\mathrm{Ma}$ lar J. 2017; 16, 418.

[29] Ponce C, Kaczorowski F, Perpoint T et al. Diagnostic accuracy of loop-mediated isothermal amplification (LAMP) for screening patients with imported malaria in a non-endemic setting. Parasite. 2017; 24, 53.

[30] Cheaveau J, Nguyen H, Chow B, et al. Clinical validation of a commercial LAMP test for ruling out malaria in returning travellers: a prospective diagnostic trial. Open Forum Infect Dis. 2018; 5(11): ofy260.

[31] Frickmann H, Hinz R, Rojak S et al. Evaluation of automated loop-mediated amplification (LAMP) for routine malaria detection in blood samples of German travellers - A cross-sectional study. Travel Med Infect Dis. 2018; 24, 25-30.

[32] Kollenda H, Hagen RM, Hanke M, et al. Poor diagnostic performance of a species-specific loop-mediated isothermal amplification (LAMP) platform for malaria. Eur J Microbiol Immunol. 2018; 8, 112-8.

[33] Vincent JP, Komaki-Yasuda K, Iwagami M, Kawai S, Kano S. Combination of PURE-DNA extraction and LAMP-DNA amplification methods for accurate malaria diagnosis on dried blood spots. Malar J. 2018; 17, 373.

[34] Burdino E, Calleri G, Ghisetti V. Added value of loopmediated isothermal amplification technology (LAMP) in real life for the diagnosis of malaria in travellers. $J$ Travel Med. 2019; 26 (7), taz052.

[35] Notomi T, Okayama H, Masubuchi H et al. Loop-mediated isothermal amplification of DNA. Nucleic Acids Res. 2000; 28, E63.

[36] Britton S, Cheng Q, Grigg MJ, et al. Sensitive detection of Plasmodium vivax using a high-throughput, colorimetric loop mediated isothermal amplification (HtLAMP) platform: a potential novel tool for malaria elimination. Plos Neglect Trop Dis. 2016; 10 (2), e0004443. [37] Mori Y, Nagamine K, Tomita N, Notomi T. Detection of loop-mediated isothermal amplification reaction by turbidity derived from magnesium pyrophosphate formation. Biochem Biophys Res Commun. 2001; 289, 150-4.

[38] Kiddle G, Herdinge P, Buttigieg N, et al. GMO detection using a bioluminescent real time reporter (BART) of loop-mediated isothermal amplification (LAMP) suitable for field use. BMC Biotechnol. 2012; 12, 15.

[39] Sema M, Alemu A, Bayih A, et al. Evaluation of noninstrumented nucleic acid amplification by loop-mediated isothermal amplification (NINA-LAMP) for the diagnosis of malaria in Northwest Ethiopia. Malar J. 2015; $14,44$.

[40] Poon LL, Wong BW, Ma EH, et al. Sensitive and inexpensive molecular test for falciparum malaria detecting Plasmodium falciparum DNA directly from heat-treated blood by loop-mediated isothermal amplification. Clin Chem. 2006; 52, 303-6.

[41] Han E-T, Watanabe R, Sattabongkot J, et al. Detection of four Plasmodium species and genus- and species-specific loop-mediated isothermal amplification for clinical diagnosis. J Clin Microbiol. 2007; 45, 2521-28.

[42] Antinori S, Mediannikov O, Corbellino M, et al. Louse-borne relapsing fever (Borrelia recurrentis) in a Somali refugee arriving in Italy: a re-emerging infection in Europe? Plos Negl Trop Dis. 2016; 10 (5), e0004522.

[43] Jelinek T, Bisoffi Z, Bonazzi L, et al. Cluster of African trypanosomiasis in travellers to Tanzanian national parks. Emerg Infect Dis. 2002; 8 (6), 634-5.

[44] Antinori S, Galimberti L, Grande R, et al. Chagas disease knocks on our door: a cross-sectional study among Latin American immigrants in Milan, Italy. Clin Microbiol Infect. 2018; 24: 1340e1-1340e6.

[45] Selvarajah D, Naing C, Htet Htet N, Mak JW. Loop-mediated isothermal amplification (LAMP) test for diagnosis of uncomplicated malaria in endemic areas: a meta-analysis of diagnostic test accuracy. Malar J. 2020; 19, 211. 